\title{
Patents and Industrialisation
}

An Historical Overview of the British Case, 1624-1907

\author{
Christine MacLeod \\ Department of History \\ University of Bristol \\ Alessandro Nuvolari \\ Laboratory of Economics and Management \\ Sant'Anna School of Advanced Studies, Pisa
}

\section{A Report to the Strategic Advisory Board for Intellectual Property Policy (SABIP)}

This research was commissioned by SABIP as an independent input to evidence for policy, and is published by the IPO.

\section{Acknowledgments}

This paper has benefitted from several insightful observations by the members of the SABIP editorial review panel, chaired by Prof. John Pickering 


\section{ABSTRACT}

This paper aims to provide a critical survey of patent systems during the first phase of the industrialisation process with a special focus on the British case. Perhaps surprisingly, there is no consensus yet on whether the emergence of modern patent systems exerted a favourable impact on inventive activities in this historical phase. However, the recent literature has shed light on a number of fundamental factors affecting the links between inventive activities and the patent system. The concluding section of the paper outlines some "history lessons" for the current debate on the role of patent in economic development. 


\section{Contents}

$1 \quad$ INTRODUCTION 1

2 ANTECEDENTS 5

3 THE ENGLISH PATENT SYSTEM, 1660-1852 8

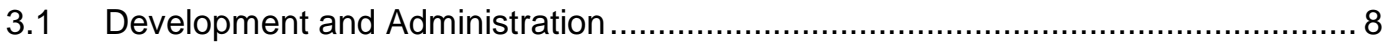

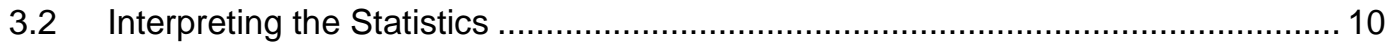

4 INVENTIVE ACTIVITY OUTSIDE THE PATENT SYSTEM 14

5 COLLECTIVE INVENTION IN A WIDER CONTEXT 18

6 THE PATENT CONTROVERSY 21

7 PATENTS AND INDUSTRIALISATION IN INTERNATIONAL PERSPECTIVE

8 THE UK PATENT SYSTEM, 1852-1907 25

$9 \quad$ CONCLUDING REMARKS 28

10 REFERENCES 31 


\section{INTRODUCTION}

The importance of patents for economic development, in general, and for British industrialisation, in particular, remains highly controversial. According to Nobel laureate Douglass North, 'by 1700 ...England had begun to protect private property in knowledge with its patent law. The stage was now set for the industrial revolution.' (North \& Thomas 1973: 155-6; also North 1981: 164-6). Dutton's study of the English patent system between 1750 and its reform in 1852 lends influential support to North's views (Dutton 1984: 202-5). Yet, Khan and Sokoloff's research suggests that North's argument may be more relevant to the United States than to England (Khan 2005; Khan and Sokoloff, 2001). Indeed, Khan and Sokoloff contend that deficiencies in its patent system were actively responsible for nineteenth-century Britain's relatively poor economic performance (Khan and Sokoloff 1998: 292-313). However, other scholars have been sceptical of any such direct, causal relationship between patents and industrialisation. Ashton, for example, considered that, 'It is at least possible that even without the patent system, discovery might have developed just as rapidly as it did' (Ashton 1948: 10; also Plant 1934; Landes 1969: 64; Mathias 1969: 34; MacLeod 1988; Greasley and Oxley 2007; and somewhat more ambiguously, Allen 2009). Over the past two decades, the emergence and development of patent systems has become a vital area of historical inquiry embracing economic, social, technological, industrial and intellectual history. However, notwithstanding these renewed research efforts, historians such as Mokyr (2002: 295) notice that much remains to be done and 'the] exact relation [of patenting] to technological progress is still obscure'.

Moreover, the nature of the industrial revolution itself has taxed economic historians for nearly two centuries, with little sign of imminent closure. Interrelated questions - what exactly it was, when, where and how it occurred, and, of course, what caused it - continue to fuel debate (MacLeod 2007: 136-44; Coleman 1992: 1-42; Cannadine 1984). Crafts and Harley's analysis of the dynamics of productivity growth both at aggregate level and for the manufacturing sector probably represents the prevailing consensus on the pace and timing of economic change (Crafts and Harley, 1992). Crafts and Harley's estimates suggest that the British economy grew more slowly before 1830 than previously believed: there was no 'take-off', no sharp upturn in economic growth in the late eighteenth century. Instead, there was a gradual and slight

\footnotetext{
${ }^{1}$ This paper has been prepared as a report for the Strategic Advisory Board on Intellectual Property Policy (project on "The Role and Rationale of Intellectual Property").
} 
acceleration over at least two centuries, which slowly took Britain to a new plane of economic activity: until the 1830s, GDP was growing at less than $2 \%$ per annum and GDP per head of population at considerably less than $1 \%$ per annum. Underlying this slow pace of economic growth was a relatively low rate of productivity growth in manufacturing, most of it concentrated in the cotton and iron industries. According to Crafts, 'not only was the triumph of ingenuity slow to come to full fruition, but it also does not seem appropriate to regard innovativeness as pervasive.' (Crafts 1985: 85; cf. McCloskey 1981 offers an opposite viewpoint) Furthermore, it has also been established that innovations took longer to diffuse than was once believed and the second half of the nineteenth century is now recognised as the period that witnessed the massive growth in steam power and in factory-based employment (von Tunzelmann, 1978). And, while population grew continuously from the mid-eighteenth century, the standard of living only began to rise significantly from the 1850 s (Musson 1976; Samuel 1977; Feinstein 1998).

These reassessments of the contours of the British industrial revolution, combined with the recent adoption of a global perspective that takes a broader geographical sweep and a longer chronological perspective (Pomeranz 2000; Inikori 2002, Allen, 2009), have the effect of reducing the prominence of that classic fifty to seventy year period, from 1760 or 1780 to 1830 , which is now less and less easily packaged as 'the Industrial Revolution' (Pollard 1981, MacLeod 2004). Nonetheless, the term (its distinctiveness often downplayed by lower case initial letters) continues to provide a convenient short-hand to refer to the first epoch of industrialisation that promoted Britain's rise to economic predominance-to its becoming during the mid-nineteenth century 'the workshop of the world', the leading producer and exporter of manufactured goods.

Technological change has been at the heart of many explanations of British industrialisation (for example, Mantoux 1928, Ashton 1948, Landes 1969, McCloskey 1981, Berg 1994, Mokyr 2002, Allen 2009), even if some, seeking to avoid anachronism, now re-describe it as 'useful knowledge' and suggest that the customary emphasis on mechanisation should be reformulated to include a wider range of techniques, capabilities, skills and 'know-how' (Mokyr, 2002). In Mokyr's succinct formulation: 'The key to the Industrial Revolution was technology, and technology is knowledge' (Mokyr 2002: 29). Moreover, whatever its initial role, it would be hard to deny that extensive technological 
change has been responsible for major increases in productivity during the past two centuries.'

The emphasis on the discontinuity in the processes of accumulating technological knowledge leaves unresolved, however, the issue of the type of technological change involved. For the Victorians, it was simple: Britain's rise to global economic predominance rested on the mechanisation of the cotton industry, coupled to the power of the steam engine (Coleman 1992: 36-42; MacLeod 2007: 1-4, 136-44). It is no longer accepted, however, that 'whoever says industrial revolution, says cotton' (Hobsbawm 1962: 49-53). Nor, in the wake of research into the pace of its diffusion, are we inclined to allow the stationary steam engine the starring role allotted it by the Victorians-certainly, not before the mid-nineteenth century. Until then, water-wheels continued to provide most mechanical power (Musson 1976, Von Tunzelmann 1978, Kanefsky 1979, Tann 1988, Crafts 2004). A less heroic view of the British industrial revolution has consistently proclaimed the importance of coal, as part of a long-term shift to fossil fuels that constituted a fundamental transition from a finite organic economy, based on land, wood and water, to an economy liberated from the constraints of land by its exploitation of the mineral resources beneath it. This interpretation of British industrialisation as a gradual energy revolution that came to fruition in the mid-nineteenth century is not without its patents, but it has generally assumed a more incremental, more anonymous model of technological change (Nef 1932, Cipolla, 1962, Harris 1976, Flinn 1984, Thomas 1985, Wrigley 1988, Allen 2009).

Inevitably, these reassessments of the nature of the industrial revolution have also entailed a reconsideration of the role played by the patent system in such a process. These historiographical changes require us to examine the development of the English patent system over the longer term and in a wider, geographical and technological context. For North, writing in the early 1970s, it was sufficient to point out the temporal proximity between the Statute of Monopolies and the classic take-off period (1760-1830) of the industrial revolution, to put forward a post hoc, ergo propter hoc (after this, therefore because of this) speculation about a causal link between the patent system and the industrial revolution. Instead, the ongoing reappraisals of the exact pace, timing and scope of economic change suggest that we need further research to provide more detailed assessments of the complicated relationships between patents, inventions and productivity in this historical phase. It is this most recent literature that we intend to survey here. 
First, we explore the antecedents, the medieval origins of European patent systems and the legislative foundation of England's system in the Statute of Monopolies. Then, we analyse the long-term upward trend in patenting that begins in 1757 and coincides so neatly with the classic Industrial Revolution dates (Sullivan 1989), to enquire how far the patents may be taken as a proxy for inventive activity in this period. This exercise reveals extensive innovation not covered by the patent statistics, and leads to an examination of innovation achieved through 'collective invention'.2 In section 6, we investigate the controversy sparked by the legislative reform of the UK patent system in 1852 that almost resulted in its abolition; and in section 7, the British case in international perspective. In section 8 we discuss the resurgence of the system, strengthened by further reforms between 1883 and 1907. Finally, we suggest that, to understand the workings of the patent system, it is helpful to think of it as a technology in its own right: as with all technologies, it was shaped by the circumstances of its invention and development. Patents had as much to do with investing as with inventing, with capitalism as with creativity. The marks of the oligarchic polity that moulded the patent system during the eighteenth century persisted throughout the nineteenth. Despite statutory reforms in 1852 and 1883, it remained expensive and barely fit for purpose, leaving much inventive activity unregistered in its (belatedly systematised) records.

\footnotetext{
${ }^{2}$ By 'invention' we understand an addition to knowledge in the technological domain; by 'innovation', its first commercial adoption.
} 


\section{ANTECEDENTS}

The origins of Europe's patent systems may be traced to the occasional privileges issued by medieval rulers, principally to immigrant craftsmen who offered to introduce new manufactures or techniques in return for princely protection and other local benefits (May 2002, Long 1991). These grants conferred no monopoly but encouraged artisans to settle and transmit their knowledge and know-how to native apprentices. The migration of skilled workers and engineers was the primary channel through which technology was transferred, both within and between countries (Davids 1995, Epstein 1997). As local guilds battled to retain trade secrets exclusively for their members, privileges became weapons in the hands of rivals to lure ambitious or dissatisfied guildsmen and elicit their secrets. This cat-and-mouse game was particularly intense among the Italian city states (Belfanti 2004).

It is not surprising, therefore, that Florence granted Europe's first exclusive patent, in 1421, to the architect Brunelleschi for the barge and hoisting gear he would use on the Arno to transport marble for his famous dome. Nor that, in 1474 , Venice was the first state to regularise by statute the award of monopoly patents: by registering an invention, the patentee secured the sole benefit of its use for ten years, with a penalty of 100 ducats for infringement - except by the state which reserved its right to free use (May 2002: 13). The bill's opening statement encapsulated the link between mobility and innovation: 'Men with most acute minds able to conceive various ingenious devices reside in this City and, thanks to its greatness and tolerance, move here every day from different countries' (Biagioli 2006: 148). But, artisans in search of advancement also emigrated from Venice, especially its highly skilled glassmakers, who disseminated knowledge of its patent system when they negotiated their settlement with other city states and Europe's rulers. 'One way or another, Italian influence shows like a thread in all incipient patent systems' (Frumkin 1947: 52).

In England, Elizabeth's chief minister, William Cecil (later Lord Burghley) revived the medieval practice of awarding royal privileges to foreign artisans as a major arm of policy, extending it to Englishmen who imported new manufactures or invented new products and processes previously unknown in the kingdom. With England still lagging behind its continental neighbours in many fields of technology, import substitution was at the centre of Cecil's schemes: grants stipulated that goods should be cheaper than their imported 
equivalent, there should be no delay in implementing the new manufacture and English apprentices should receive a full training. Moreover, guilds and other established interests were consulted to avoid inflicting harm and provoking discord (MacLeod 1988: 11-13). Results were mixed, however: Burghley lost heart and, gradually, malpractices crept in. Elizabeth and her successor, James $I$, found in the issue of licences a much-needed source of patronage and revenue. Privileges could still be obtained for the introduction of foreign (and native) inventions, especially for those with influence at Court. But, more controversially, monopolies were increasingly granted where there was no innovation to courtiers and their clients, with harmful effects on both tradesmen and consumers (Duncan 1976: 99, 116-31, 147-73; Thirsk 1978: 86-7, 95-101).

As a result, England came close to abolishing its nascent patent system a century and a half before the Industrial Revolution conventionally began. In 1623, with popular anger erupting against these misuses of the royal prerogative, parliament enacted the Statute of Monopolies (21 Jac.l c.3). Its purpose to prevent further such abuse, the Statute specifically preserved the monopoly privileges granted to inventors and to importers of invention. Section 6 limited patents of invention to a fourteen-year term, to 'new manufactures within this realm' and to their 'true and first inventor', excluding anything illegal or deemed harmful to the state or the public interest. Their validity could be tried at common law (MacLeod 1988: 14-19). For the next two and a quarter centuries, until the passage of the Patent Law Amendment Act of 1852, this clause of exemption provided the fundamental legislative basis of the English patent system.

Charles I, even more desperate for revenue, contrived to ignore the Statute, with the result that the patent system was totally discredited and effectively dismantled by the Long Parliament in 1640 (Yamomoto 2010: 60-3). 'Monopoly' had become a highly emotive word, and retains its pejorative force to this day. At the Restoration, the patent system was re-established under the watchful eye of public and parliament. While the later Stuarts often sailed close to the wind (courtiers and office-holders received preferential treatment, and patents might be over-ridden by subsequent grants or disallowed because they jeopardised royal revenues), the regular fiscal exploitation of patents was not revived. On the other hand, there is no evidence of the use of the system as an industrial policy tool as in Burghley's period (MacLeod 1988: 20-39; Yamomoto 2010: 7485). The routine administration of the English patent system was the epitome of laissez-faire. It registered the inventor's claim and took his money (lots of it), but 
left the question of his reward to the market and the business of regulating or enforcing the patent to the litigation of the civil courts (cf. Hilaire-Pérez 2000). 


\section{THE ENGLISH PATENT SYSTEM, 1660-1852}

\subsection{Development and Administration}

Before 1852, there was no dedicated patent office, only a tortuous route through the royal bureaucracy laid down by the Clerks Act (1535) for all grants of the crown under the great seal. An applicant's petition for 'letters patent' was referred to one of the crown's law officers (Attorney or Solicitor General), who was required to check that the patent would not contravene the Statute of Monopolies -- or harm the royal interest, for example, by reducing the revenue from excise duties. There was no formal examination for novelty or utility, and very few applications were refused. ${ }^{3}$ Yet, the applicant still had to negotiate a bureaucratic maze: his patent would not be enrolled until he had accumulated an expensive series of seals and signatures, waiting on officials, paying fees and favours at every stage (Gomme 1946: MacLeod 1988: 40-8). This timeconsuming process added to the cost, especially for anyone not resident in London. One Manchester inventor's diary shows him spending six months in the capital during 1722-3 (Gomme 1934-5: 210-16).

To secure a patent for England and Wales cost approximately £100; to extend it to Scotland and Ireland, another £200--250 (plus more time and effort). A patent agent's services, which the system's growing complexity (especially the specification) made increasingly desirable, added a further £40-£100 (Dutton 1984: 86-96; Khan and Sokoloff 1988: 300). It was an enormous expense when a skilled worker earned between $£ 1$ and £2 a week. Charles Dickens famously lampooned this bureaucratic excrescence in his 'Poor Man's Tale of a Patent' and Little Dorrit. The poor man afforded his patent only through that common Victorian literary device of a chance inheritance (MacLeod 2007: 184-6).

And, yet, there remained the specification to be filed. This requirement to provide a more detailed description of the invention (within two to six months of the patent's enrolment) was introduced ad hoc during the first third of the eighteenth century; from 1734, it became standard. Although initially demanded to assist the law officers in discriminating among ostensibly similar inventions (possibly in case of a challenge before the Privy Council), the specification was

\footnotetext{
${ }^{3}$ One of the very few examples of a patent that was refused the great seal of which we are aware is the curious patent for "a new invented medicine consisting of a liquid, which by washing the part, in men, any time within eight hours after coition absolutely prevents the communication of the venereal disease, let it be of any degree or virulence, whatsoever" applied for by the chemist Samuel Hannay in 1774.
} 
not normally scrutinised by any administrative department of government. As a result, many specifications remained extremely opaque (MacLeod 1988: 48-55). It would be subjected to close judicial scrutiny, however, if the patentee prosecuted an infringement: where insufficiently full or accurate, it threatened the patent's validity. Indeed, the specification became the patent's most vulnerable aspect, but patentees hopeful of avoiding litigation might still prefer obfuscation. There remained much judicial uncertainty: while exactness risked allowing competitors to circumvent the patent via a minor variation, a too general a claim exposed the specification to a successful legal challenge (Adams \& Averley 1986: 156-79). It was anxiety concerning the validity of his specification that notoriously deterred James Watt from immediately prosecuting some infringements of his patent for the separate condenser; fearful that his specification would be found insufficiently precise, for a long time he preferred not to risk losing his patent (Robinson 1971, Miller 2006). Specification also added to the costs of patenting. A specification that would withstand the test of both litigation and piratical cunning placed a premium on good draughtsmanship. One leading engineer in 1851 put the cost of patenting 'a complex machine, or system of machines' at $£ 500-600$, because of having to provide extended and complicated specifications ([House of Lords] 1851: 429).

Prior to 1753, a patentee could appeal to the Privy Council for support in the enforcement of his rights: infringement was deemed tantamount to contempt of the royal prerogative. The Privy Council had the option of referring a case to the civil jurisdiction of the common law courts; finally, prompted by an especially thorny case in 1752, it entirely ceded them its authority (Hulme 1917; MacLeod 1988: 58-60). Patentees now had no alternative to the expense and delay of the legal system. The reluctance to prosecute engendered by these factors was exacerbated by the extreme uncertainty surrounding the law of patents. What constituted a patentable 'invention' under the Statute of Monopolies only began to be determined once the Privy Council relinquished its jurisdiction in the mid-eighteenth century, and the case law was slow to compensate for the vagueness of an outdated statute. In 1795, Chief Justice Eyre, sitting in the case of Boulton and Watt vs Bull, complained that 'patent rights are nowhere that I can find accurately described in our books' (Holdsworth 1922-72: XI, 425). He was echoed, three decades later, by a witness to parliament's first investigation since 1623 into the patent system, who told the 1829 select committee that 'there being no existing basis of law, the dictum of the judge is one thing one day and another thing another'. Or, in Marc Isambard Brunel's 
pithier phrase, 'I might as well toss for the fate of a patent' ([Select Committee on Patents] 1829: 454, 486).

The imprecision and unpredictability of the law seems to have been exacerbated until the 1830s by a prejudice among judges and juries against patentees. Dutton refers to 'the excessively hostile attitude of some judges' who, perhaps unsurprisingly in the historical and legal context, were on their guard against the abuse of the monopoly privilege that a patent conferred. They were regularly accused of interpreting the law in the strictest possible way, willing to cancel a patent for some trivial error of clerical copying (Dutton 1984: 77-8). Dutton finds that between 1750 and 1829 only a third of judgements at common law went in favour of the patentee; in the 1830s and 40 s this jumped to three-quarters (76\%), and judges themselves commented on the recent change in attitudes (Dutton 1984: 78-9; MacLeod 2007: 69-81, 183-9). ${ }^{4}$

\subsection{Interpreting the Statistics}

After a century of stagnation in which the annual total of patents granted fluctuated between zero and 23, but was normally in single figures, the 1760 s saw the beginning of a new trend-a long-term increase from an annual average of 20 in that decade to over 60 in the 1790s, rising to more than 450 in the 1840s (Mitchell and Deane 1962: 268-9; Sullivan 1989). ${ }^{5}$ Does this reflect an upsurge in inventive activity $?^{6}$ Is it evidence for a stimulus to invention from the patent system? Alternatively, is it indicative of nothing more than an increasing propensity to patent? Whether or not it represents a real surge in inventive activity is impossible to determine conclusively, but the argument for its reflecting some autonomous increase in the propensity to patent merits restatement, especially now that the chronology of the classic Industrial

\footnotetext{
${ }^{4}$ A more favourable picture is emerging from Sean Bottomley's research, which implies a more certain legal situation than Dutton and MacLeod suggest: 'Patent disputes in the English law courts, 1753-1799', presented to ESTER Advanced Seminar, Eindhoven University of Technology, 23-26 June 2009.

${ }^{5}$ Deflating the figures by population totals produces a much less impressive rate of increase before the 1830s (Khan and Sokoloff 1998: 299)

${ }^{6}$ Sullivan $(1989,1990)$ has argued that the evidence of patent counts lends support to the traditional view of the industrial revolution, as they exhibit a sharp acceleration taking place across a broad industrial front around 1760 and this finding contradicts the Crafts and Harley's account of a slow and relatively concentrated process of economic change. Nuvolari and Tartari (2010), on the basis of new estimates of the quality of individual patents, have suggested a reconciliation between these viewpoints, arguing that, although total patents were widespread, high quality patents emanated from a very restricted number of key sectors.
} 
Revolution has been undermined by Crafts' and Harley's calculations (MacLeod 1988: 144-57). ${ }^{7}$

Patenting an invention was by no means common or automatic. During this period, the patent system was still an embryonic institution-indeed it was still in search of a specific role. Although it was not subject to serious legislative interference between 1624 and 1852, it was very adaptable. It emerged from the seventeenth century deeply scarred both by its association with monopolies and royal favouritism and, more recently, by its implication in the stock-market bubble of the 1690s--a phenomenon repeated in 1717-20 (MacLeod 1986; Yamomoto 2010: 281-96, 346-7). Few inventors other than those with connections to the Court or the City of London were likely to have been aware of its existence; or if they were, to have seen its relevance to their activities. This began to change, but only slowly. Developments in transport and communication during the eighteenth century promoted awareness of the patent system at the same time as they stimulated the growth of a national market in commodities and in factors of production. In particular, faster coaching services and the regular publication of newspapers, journals, advertisements and other publicity materials carried news of patented inventions and patent litigation into the provinces. The 1790s saw the launch of specialist journals, such as the Repertory of Arts and Manufactures, which listed patents and critiqued new inventions. The broadening geographical distribution of patents is testimony to such an extension of awareness: it doubled from 19 counties where at least one patent was obtained in the 1750s to 38 counties in the 1790s (MacLeod 1988: 77-8, 126-7).

A positive feedback mechanism developed. The more patents issued, the greater both the public's awareness of them and the pressure to obtain them. The patent system generated its own defensive logic: inventors began to realise that neglecting to patent an invention might mean losing it to someone more pro-active, who would demand a royalty for its continued use or production. Such anxieties appear in inventors' correspondence - informing, for example,

\footnotetext{
${ }^{7} \mathrm{~A}$ recent analysis of the nature of the co-integration between the time series of patents and those of industrial output in various sectors for the period (1780-1851) performed by Greasley and Oxley (2007) reveals that the causality links run mostly from the dynamics of industrial output in a restricted number of key-sectors (cotton, iron and mining) to the series of aggregate patents. In Greasley and Oxley's interpretation, this result suggests that the rise of patenting was a consequence and not a cause of the acceleration of industrial output growth. A similar view, positing that the acceleration of industrial output led to a growth in the demand of patenting, was originally sketched by Ashton (1948). See also MacLeod (1988, ch. 8).
} 
the decisions of James Watt and his friends as they debated whether or not to incur the expense of a patent (Dutton 1984: 183-5; MacLeod 1988: 89-90).

Other major trends increased the propensity to patent, not least the long-term restructuring of the economy, with its concomitant redirection of capital and labour from agriculture into the manufacturing and service sectors (Crafts 1985: 60-4). The agrarian sector, which had dominated the pre-industrial economy, generated few patents: while still employing over a third of the workforce in 1800, it accounted for less than four per cent of patents (MacLeod 1988: 97). Consequently, as employment in manufacturing and services expanded both absolutely and relatively during the eighteenth and nineteenth centuries, so did the pool of inventors with a higher propensity to patent. Another important trend conducive to patenting was urbanisation (MacLeod 1988: 125-9). ${ }^{8}$ Since the vast majority of patentees were based in towns and cities, the growth of Britain's urban population (19 per cent of total population in 1700, 23 per cent in 1750, 35 per cent in 1800, 54 per cent in 1850, and 75 per cent in 1900) would independently stimulate the propensity to patent.

Patentees clustered in those parts of the country and sectors of the economy that had moved furthest towards a hierarchical, competitive and capitalintensive economic structure. Throughout this period, Londoners predominated: with approximately one tenth of England's population and one quarter of its manufacturing output, the capital city consistently obtained over half of all patents (Dutton 1984: 87-8; MacLeod 1988: 118-25). To some extent, this reflects their proximity to the bureaucracy and greater awareness of the system, but it is also symptomatic of the increasingly capitalistic organisation of London's manufacturing sector, in particular its higher-status crafts. A further quarter of English patents were taken out by residents of the manufacturing districts in the midlands and north-especially the metalworkers of Birmingham, the textile manufacturers of Lancashire and Yorkshire, and the hosiers of Nottingham and its region (Dutton 1984: 88-9; MacLeod 1988: 124-34).

In the second half of the eighteenth century, the textile industries (including hosiery and lace) and the metalworking industries each accounted for approximately 14 per cent of English patents. It was a period that saw major strides in the centralisation and capitalisation of these industries. The domestic organisation that typified most of the textile industries had not been conducive

\footnotetext{
${ }^{8}$ Sokoloff remarked the same phenomenon in the early USA, though he ascribed higher levels of patenting in urban centres to higher rates of inventive activity (Sokoloff 1988, Sokoloff and Khan, 1990).
} 
to patenting: manufacture's diffusion over a wide area, often in remote cottages, made enforcement very difficult (as John Kay discovered when he tried to collect royalties from Lancashire weavers using the flying shuttle). The more centralised and highly capitalised sectors of industry obtained more patents: the silk industry (with its early 'throwing' factories) and the finishing processes in all sectors were predominant in the patent records before 1770 . Thereafter, the reorganisation of cotton and worsted spinning into factories prompted an upsurge in their patenting. Not only was a patent easier to police in a factorybased industry, but it was also potentially more valuable as these industries grew exponentially (MacLeod 1988: 102-3). Khan and Sokoloff similarly emphasise the impetus from 'centralized plant organization . . . [to] more rapid technical change over time', and point to the greater prevalence of cottage manufacture in Britain as a major reason for its lower rate of productivity growth in comparison with the USA's (Khan and Sokoloff 1998: 307-8). In the metalware trades Birmingham, its manufacturing concentrated in fewer, richer, more competitive hands than its rivals', outpaced them all in obtaining patents -- 90 by 1800 (MacLeod 1988: 130; Berg 1991; Berg 1998). 


\section{INVENTIVE ACTIVITY OUTSIDE THE PATENT SYSTEM}

Without a patent system, it is doubtful that eighteenth-century Britain would have seen significantly less inventive activity, since most inventors ignored it. Of course, detailed quantitative assessments of the amount of inventive activity undertaken outside the coverage of patent protection remain inherently speculative. The appeal of patents for economists and economic historians largely stems from the opportunity to study systematically the full universe of patented inventions. By contrast, any sensible catalogue of the inventions that remained unpatented is likely to be fraught by omissions and related biases, or restricted in long-term comparisons. Moser's $(2005,2010)$ research on the inventions presented at the Crystal Palace exhibition of 1851 probably provides the best quantitative snapshot of the large volume of inventive activity undertaken outside the patent system in the mid-nineteenth century. None of the British or American industries she considers had patenting rates (i.e., the ratio between patented inventions and total inventions) higher than 50 per cent. The highest value she reports is 36.4 per cent for the US machinery industry. ${ }^{9}$

These aggregate results are supported by 'micro-evidence' emerging from detailed histories of inventors, industries and specific technologies. Famous examples of unpatented inventions include Crompton's spinning mule, Trevithick's high-pressure steam engine and Jenner's vaccination against smallpox. At least two highly innovative manufacturers, Josiah Wedgwood and Jesse Ramsden, renounced patents subsequent to an early disillusionment (MacLeod 1988: 111; McConnell 2007). Harrison's chronometer was famously invented in response to the Longitude Act of $1713,{ }^{10}$ and much inventive activity is captured in the records of institutions such as the Royal Society of London and the Society of Arts, which from 1754 offered premiums and prizes for invention (MacLeod 1988: 193-5; Hilaire-Pérez 2000: 189-209; O’Brien et al.

\footnotetext{
${ }^{9}$ Interestingly enough, Moser's findings are similar to those emerging in modern studies on the propensity to patent. In these studies, patents are reckoned by R\&D managers to be the most effective tool for appropriating economic returns from invention only in a few selected industries such as chemicals and pharmaceuticals. Instead in the majority of contexts, secrecy, lead times and the control of complementary assets are recognised to be more effective tools than patents for protecting inventions (Levin et al., 1987; Cohen, Nelson and Walsh, 2000).

${ }^{10}$ According to Boehm and Silberston (1967: 25-6), between 1750 and 1825 there were at least eight Acts of Parliament instituting prizes for specific inventions. Furthermore, in several cases particularly deserving inventors were also compensated by Parliament by means of ex-post rewards.
} 
1996). ${ }^{11}$ Furthermore, a large volume of inventions were of an incremental nature, and consequently anonymous and detectable only by their effects. Although often overlooked in assessments of patenting, the crucial importance of (usually unpatented) incremental improvements is widely acknowledged in both histories of industrialisation and modern empirical studies of innovation (Landes 1969, Mathias 1969, Rosenberg 1976, Von Tunzelmann 1981).

Technological change in major sectors of the economy raised productivity or offered consumers a widening range of goods, on a scale that was scarcely hinted at in the patent records. A striking example of the former was the agricultural sector, with only four per cent of eighteenth-century patents. Yet, 'between 1300 and 1800 the average yield of wheat rose from about 12 bushels per acre to about 20 bushels'; the output per acre of other crops realised similar or greater increases (Allen 2008: 182; Crafts 1985: 83-4). This 66 per cent increase in yields was achieved principally after 1600, through the introduction of nitrogen-fixing crops in new rotations, which left hardly a trace in the patent records. ${ }^{12}$ Also of importance in raising (both land and labour) productivity were improvements in drainage, manures, seeds, and implements (Allen 2008: 202; Wrigley 1985). A small range of drainage devices and a few implements were patented, the latter mostly after 1780-a development stemming from the emergence of specialist manufacturers of agricultural implements-but their number was scarcely commensurate with the improvements in this sphere. Similarly, the gains made through selective breeding of livestock went unpatented. These technical advances raised the productivity of both land and labour, releasing a growing proportion of the workforce into the industrial and service sectors (Bairoch 1973). Where not anonymous, they were rewarded rarely with patents, more often with prizes from agricultural and improvement societies or sometimes they were protected by copyright in agrarian treatises (MacLeod 1988: 98, 193-5).

The mining industry produced even fewer patents, despite growing in economic importance, its output expanding rapidly in volume and value. As mines

\footnotetext{
${ }^{11}$ Interestingly enough, at least in principle, the award system of the Society of Arts, was opposed to patents, as the "Rules and Notices of the Society" stated explicitly that "no person shall receive any premium, or bounty from the Society, for any matter for which he has obtained or proposes to obtain a patent" (Harrison, 2006: 163). A recent study by Brunt et al (2008) of the prizes for invention awarded by the Royal Agricultural Society of England over the period 18391939 shows that prizes could be very effective stimuli for inventive activities.

${ }^{12}$ A major recent study by Olmstead and Rhode (2008, esp. 400-1) has also stressed the fundamental role of a stream of biological innovation in American agricultural development throughout the nineteenth century taking place long before the first formal legal protection (Plant Protection Act of 1930).
} 
became deeper and seams were worked further and further underground, a host of new technical challenges had to be met. Yet, the extraction of coal and ores scarcely featured in the patent records: only three patents were obtained for rock-boring tools or blasting techniques during the eighteenth century; and only three for proposed solutions to the pressing problems of ventilation and 'fire-damp' (explosions). The productivity of the mining industry was raised in large part by the incremental adjustments to techniques practised by miners and skilled managers. Patentees were attracted instead to the solution of strictly mechanical problems in the mining industry-in particular, drainage and winding engines-that were visible on the surface, easily described, and represented a significant capital investment. A patent for such engines was both more easily policed and more marketable than the empirical improvements being devised underground (Flinn 1984: 74-128; MacLeod 1988: 100-2).

Nonetheless, there is also evidence of extensive inventive activity in this mechanical sphere beyond the purview of the patent system. Cornish mining engineers, resentful of Watt's extended patent for the separate condenser, turned their backs on the patent system: Cornwall's share of English patents for steam-related inventions fell from approximately ten per cent in the eighteenth century to less than one per cent in the period 1813-52 (Nuvolari 2004: 358). Yet, this period witnessed Cornwall gaining predominance in steam engineering. It started with Richard Trevithick and Arthur Woolf erecting highpressure steam engines in Cornish tin and copper mines, where high coal prices made thermodynamic efficiency essential. It persisted through the empirical discovery and dissemination of best-practice techniques, in particular through their publication in Lean's Engine Reporter. The 'duty' of Cornwall's high-pressure engines nearly doubled in a quarter of a century. Nuvolari shows that the phenomenon of 'collective invention', first identified by Allen (1983) in the Cleveland iron industry of north-eastern England between 1850 and 1875, also operated in the Cornish mining district. Firms shared pertinent technical information concerning variations in design and performance, and utilised this shared knowledge to improve their technology (overwhelmingly by incremental inventions). Both the complex, empirical nature of the technology and the diverse structure of the Cornish mining industry (adventurers usually held shares in several mines) favoured the collective pursuit of improvements in the aggregate average performance of pumping engines. The publication of performance indicators allowed the best engineers (employed by the mines to erect and maintain their steam pumps) to demonstrate their capabilities, thereby enhancing their professional reputations and career prospects (Nuvolari 2004). 
Similar priorities informed the nascent civil engineering profession, responsible for the innovations in transport and communications that we commonly identify with the industrial revolution. The problem-solving activity that underpinned the engineering of bridges, tunnels, cuttings and embankments, whether on roads, canals, or railways, is scarcely reflected in the patent records. Civil engineers tended to share and publish their solutions (MacLeod 1988: 104-5). Again, although not as systematic as the 'collective invention' identified in Cornwall or Cleveland, a similar disregard for patents is also recognisable among other innovative groups in this period, such as London's clock and instrument makers (MacLeod 1988: 113-14; McConnell 2007), the first generation of West Riding textile engineers (Cookson 1997: 8-9), and early developers of machine tools though secrecy was probably as rife as sharing (MacLeod 1988: 105-6, 188). Paulinyi (1986) regards machine tools as the crucial technology that, by producing 'machines to make machines', opened the way for mass production: rarely patented, a stream of inventions to facilitate the cutting and shaping of metals emanated from the workshops of highly skilled craftsmen, most of whom remain anonymous and undervalued. 


\section{COLLECTIVE INVENTION IN A WIDER CONTEXT}

In his original paper, Allen (1983: 21) suggested that 'under the conditions prevailing during the nineteenth century [collective invention]...was probably the most important source of inventions.' Allen's conjecture rests on the idea that, before the establishment of corporate R\&D laboratories, inventive activities in many industries were a by-product of investment processes. In these conditions, collective invention was likely to be a very effective method of identifying the most promising direction of improvements. On the other hand, Mokyr (2008) argues that collective invention ought instead to be considered a marginal phenomenon. 'There are three reasonably well-documented cases of successful collective invention ... [Allen (1983), MacLeod (1988, pp. 112-113, 188), Nuvolari (2004)]. Examples of such cases are not many, and they required rather special circumstances that were not common, and collective invention in its more extreme form, to judge from its short life-spans, was vulnerable and ephemeral.'

There are reasons to think that Mokyr's assessment may be premature. First, it would be wrong to assume that collective invention was just a British phenomenon. For example, in his account of the development of the highpressure engine for the western steamboats in the United States during the early nineteenth century, Hunter emphasised the significance of various flows of incremental innovations (Hunter 1949: 121-80). Interestingly, Hunter suggests that the litigation of the patents taken by Robert Fulton and Oliver Evans (mirroring the conflict between Boulton and Watt and Cornish engineers) may account for the negative attitude of western mechanics towards patents (Hunter, 1949: 10, 124-6). Similarly, the steady accumulation of many minor changes and alterations to the design of the physical characteristics of the steaming produced improvements in carrying capacity, increased speeds and reduced cargo collection times. Their cumulative impact led to a rate of productivity growth without parallel in the transport technology of the period (Mak and Walton, 1972). ${ }^{13}$ McGaw's (1987) detailed study of paper-making in Berkshire (US) seems also to point to another American collective invention setting. These cases represent a challenging research agenda. Given Khan and Sokoloff's argument for the US patent system's critical role as the fundamental driver of innovation in nineteenth-century America, it would be particularly

\footnotetext{
13 "The available evidence suggests that the increase of steamboat productivity (on inland rivers), 1815-1860, exceeded that of any other major transportation medium for a period of similar length in the nineteenth century" (Mak and Walton, 1972:623).
} 
interesting to mount a systematic search for cases of collective invention in the United States.

Other cases of collective invention have been identified elsewhere. French researchers have documented systematic incentives to collective invention among guildsmen in the technologically dynamic silk industry of Lyon, which crushed its London competitors who relied on patents and secrecy (Cottereau 1997, Foray \& Hilaire-Pérez 2006). Davids (2009) argues that collective invention was also a common practice among millwrights in the Zaankstreet in the Netherlands, during the seventeenth and eighteenth centuries. The Zaankstreet, one of the cutting-edge industrial districts in Europe at that time, was the first place where wind power was adopted on a massive scale. Kyriazidou and Pesendorfer (1999) suggest that collective invention also characterised the Viennese bentwood furniture industry in the second half of the nineteenth century: it was highly successful, establishing Viennese chairs as a fashion item throughout Europe. Furthermore, Allen (2009: 68-74) argues that collective invention was not limited to industry but was also a feature of many fundamental improvements in agriculture that were introduced in England from the second half of the seventeenth century, in particular new crop rotations.

In the second half of the nineteenth century, in industries characterised by oligopolistic structures, processes of collective invention could be implemented by means of patent pools and research associations (in these cases the knowledge was shared only among the participants to the patent pool or the research association). Note that, in several cases, these patent pools were created after having experienced phases of slow innovation due to the existence of blocking patents. In the 1870s, American producers of Bessemer steel decided to share information on design of plants and performances through the Bessemer Association (a patent pool holding control of the essential patents in the production of Bessemer steel). The creation of this patent pool was stimulated by the unsatisfactory innovative performance of the industry under the 'pure' patent system regime. In that phase, the control of essential patents by different firms had resulted in an almost indissoluble technological deadlock. Similar concerns over patent blockages led firms operating in the US railway sector to adopt the same expedient of semi-automatic cross-licences and knowledge-sharing (Nuvolari, 2004: 360-1). Processes of knowledge sharing organised among firms in cartels could be a very effective tool through which backward countries could rapidly catch up with the most advanced, as illustrated by the case of the German chemical industry described by Murmann 
(2003) and the Japanese cotton spinning industry described by Saxonhouse (1974).

These cases imply that collective invention was probably not such a marginal phenomenon, as Mokyr suggests. However, even if they prove to be exceptional, they should not be dismissed as 'curious exceptions'. It is worth re-emphasising that key technologies at the heart of industrialisation, such as high-pressure steam engines, iron production techniques, steamboats and automatic looms, were at times developed through processes of collective invention, and consequently outside the purview of the patent system. All these cases provide a clear demonstration that inventive activities could be very effectively organised without resorting to patent protection. There are, of course, interesting historical parallels between collective invention and contemporary instances of innovation processes based on knowledge sharing, such as open source software (Nuvolari 2005) and the user communities identified by von Hippel and his associates (von Hippel 2005). Given the remarkable successes in the rates of innovation that seem to characterise these experiences, it is clearly important to reflect on possible policy measures that could encourage the emergence and consolidation of these knowledge-sharing communities in new technological domains (Shah 2005). 


\section{THE PATENT CONTROVERSY}

Retrospectively, these examples of 'collective invention' lend weight to Victorian calls for the abolition of the patent system, a campaign that was sparked by the Patent Amendment Act of 1852 . The UK had been slow to put its system of royal privileges on a firm statutory footing and reduce the obstacles faced by would-be patentees. Sixty years earlier, political revolutions in France and the USA had enshrined the inventor's entitlement to a patent in their respective constitutions, prompting a wave of modernising legislation elsewhere in Europe during the next two decades (Galvez-Behar 2008: 21-52; Khan 2005, 49-54). Subsequently, while the UK was still wrestling with its unreformed system, Europe-wide movements inspired by economic liberalism were already reacting against the strength of patents and demanding their abolition (Machlup and Penrose 1950). In 1851, eight of 33 witnesses who testified before a parliamentary select committee on the patent system advocated its abolition. This small but very authoritative minority, which contained several engineers including Isambard Kingdom Brunel, persuaded the committee's chairman, Lord Granville, to dissent from the report's reformist recommendations. 'The whole system', declared Granville, 'was unadvisable to the public, disadvantageous to inventors, and wrong in principle' (MacLeod 2007: 250).

Nonetheless, the 1852 act finally established a patent office, reduced the initial cost of a patent to $£ 25$ for the entire United Kingdom (it introduced renewal fees of $£ 50$ after three years and $£ 100$ after another four), and authorised the publication of patent specifications (backdated to 1617). It required specification and granted protection at the point of application, but also allowed provisional protection subject to full specification within six months (increased to 10 months in 1883). Such facilitating measures, with no official examination to counter them, raised fears of 'frivolous' inventions swamping the system and mendacious patentees harassing manufacturers. It is, however, improbable that they would have unleashed a vociferous abolitionist campaign had it not been for the clause that exempted colonial sugar-refiners from patent royalties and turned their disadvantaged British rivals into dogged free-traders determined to extirpate all patent systems (Coulter 1992).

The abolitionists' arguments were overwhelmingly pragmatic: patents constituted a harmful restraint on trade, an unjust monopoly that increased prices, an irritant to manufacturers and a fatal lure that impoverished ingenious working men. However, they also contested the individualistic model of 
invention that tacitly underpinned patenting. Technological change, they argued, had its own momentum, progressing incrementally through the accumulation of many inventive steps; in evidence, they pointed to instances of simultaneous invention. No one, therefore, either merited the reward of a patent, or needed the incentive of one to invent (MacLeod 1996; MacLeod 2007: 264-76). It is, of course, an argument that has been rehearsed many times since, not least by Chicago School sociologists (McGee 1995). In Victorian Britain, the controversy stimulated a concerted defence of inventive 'genius' by the Inventors' Institute (founded in 1862), patent agents and other interested parties. 'Smilesean' literature and works of art that celebrated the role of inventors and engineers in Britain's rise to industrial eminence reached a mass audience and helped preserve the patent system (MacLeod 2007: 251-76).

Despite two more parliamentary inquiries and almost annual draft bills being presented to Parliament, the Economist's prediction in 1869 that Britain would emulate the Netherlands' abolition of its patent system proved incorrect. The Patents, Designs and Trademarks Act of 1883 which, among other reforms, introduced a severely reduced initial fee (£4) sealed the abolitionists' defeat. Across Europe, the anti-patent movement was fizzling out as the continent (under pressure from cheap US agricultural imports) retreated from free trade. It too saw its nemesis in 1883, with the conclusion of the Paris Convention, the first international agreement on patenting, which strengthened the patentee's hand by implementing a measure of cross-border co-operation. The Convention also helped to pressurise the Netherlands into returning to the fold in 1912 and Switzerland into enacting its first (limited) federal patent law in 1888 (Penrose 1951: 15-16; Schiff 1971; Khan 2005: 289-93). Interestingly enough, according to Machlup (1958: 5; see also Chang 2001: 291), the widespread acceptance of some limitation to the monopoly power of patents, by means of compulsory licence clauses, at the Patent Congress held at Vienna's World Fair in 1873, also played a critical role in the shift of opinion against the abolitionists across Europe. 


\section{PATENTS AND INDUSTRIALISATION IN INTERNATIONAL PERSPECTIVE}

There has been insufficient research to determine conclusively whether the absence of patent systems in Switzerland and the Netherlands was to their economic advantage or disadvantage. Switzerland industrialised early, despite its difficult terrain and lack of mineral resources: it developed a mechanised cotton industry, with ancillary strengths in dyeing and hydraulic engineering, and a world-leading watch-making industry. Schiff (1971) suggests that Swiss industrialists took advantage of the absence of a domestic patent system to found important industries based on foreign inventions, such as textile machinery making (1801), synthetic dyeing (1859), and electricity generation (c.1880). Its highly successful chemical and pharmaceutical industries lobbied hard to exclude their products from the patent system until 1907, to the fury of their German competitors. Meanwhile, Swiss inventors were responsible for major inventions in these and other industries, and had a consistently high rate of patenting abroad. Khan (2005: 292), who tends to belittle Swiss industry before 1888 (as essentially cuckoo-clocks and chocolate) points to the immediate and substantial increase in the rate of Swiss patenting in the US from 1888 as evidence of increased 'inventive activity . . . induced by patent protection.' On the other hand, it may simply have reflected an increasing propensity to patent abroad once patent protection became available in Switzerland. What seems certain is that Switzerland's economy was among the fastest growing in Europe both before and after it introduced its own patent system (Carreras and Josephson 2010).

The Netherlands had enjoyed the highest incomes per head in Europe since the seventeenth century, based principally on its domination of international trade, a large proto-industrial sector and commercial agriculture. It was overtaken by the United Kingdom only in the mid 1840s and by Switzerland and Belgium in the late 1880s (Carreras and Josephson 2010). In the nineteenth century the Dutch seem to have largely ignored their own patent system, whether through lack of inventive activity or insouciance of patents. Only 4,561 patents were issued from 1800 to 1869 and, between 1851 and 1865, 88.6 per cent were obtained by foreigners (in 1912 foreigners again took 79.3 per cent of Dutch patents) (Khan 2005: 290). Most economic historians consider Dutch industrialisation to have occurred during its 'patentless' period, on a broad front and at a moderate rate with a continuing heavy involvement in international transit trade. However 
there are significant examples of Dutch industrialists taking advantage of foreign inventions to found major industries, as illustrated by the cases of the margarine industry (1871) and incandescent light-bulb manufacture (1891); the latter enjoyed major benefits by not being subject to Edison's licences and it was the basis for the creation of the Philips electrical company (Heerding, 1985: 235-85; Schiff 1971; Van Zanden and Van Riel 2004: 301).

On balance, the limited evidence that we have suggests that neither Switzerland nor the Netherlands suffered from the absence of their own patent system at a time when most other industrialised or industrialising countries kept theirs. If anything, for these two small open economies catching up with the world technological frontier, not having a patent system was probably a rational course of action, as long as it did not instigate major retaliations by the international community (Van Zanden and Van Riel 2004: 177-8). It may be wise, however, to note Khan's (2005: 294) conclusion that, 'In any event, both the Netherlands and Switzerland featured unique circumstances that hold few lessons for developing countries today. ${ }^{, 14}$

\footnotetext{
${ }^{14}$ We should also bear in mind that another option available to catching-up countries seeking to access advanced technologies was the implementation of a patent system that, in actual practice, discriminated against foreign patent owners, allowing them a reduced degree of protection against domestic imitators. See Richter and Streb (2009) for an insightful case study of the catching up activities of German machine tool manufacturers. Even when we look at the case of the US patent system that, according to Khan and Sokoloff (1998: Khan 2005), played a critical role in triggering the economic ascendancy of the United States during the nineteenth century, we should consider that the early history of the system was characterised by a significant number of discriminatory practices against foreign inventors. In particular, until 1836 foreign inventors were not allowed to take patents in the US (Khan, 2010). In this way, it was possible for American inventors to transfer technologies from abroad by patenting small modifications of foreign inventions. This was a pattern characteristic of the early history of the US cotton industry (Jeremy, 1973: Wallace and Jeremy, 1977).
} 


\section{THE UK PATENT SYSTEM, 1852-1907}

Khan and Sokoloff emphasise the high cost of British patents in comparison with the US, and demonstrate that the rate of patenting per head of US population jumped during the early nineteenth century as the social composition of patentees broadened. They conclude that the operation of the patent system in England discouraged many inventors or would-be inventors from participation in the system' (Khan \& Sokoloff 1998: 305; MacLeod 1991). Undoubtedly, the two reductions in initial fees made the UK system more widely accessible. The first in 1852 saw the total number of patents issued leap from 455 in 1851 to 2,113 in 1853 , and then rise to nearly 4,000 per annum by the early 1880 s; following the second in 1883 , it shot to 9,308 in 1885 , reaching 14,000 per annum in the late 1890s (Boehm and Silberston 1967: 22-3, 32-4; Khan and Sokoloff 1998: 299). Yet, many inventors still disregarded the patent system, finding other more appropriate means for exploiting their invention, including secrecy (Moser 2005).

Demands for reform continued, largely because of the high renewal fees introduced in 1852 and problems created by the continuing lack of official examination to test the validity of patent claims. Indeed, the two issues were closely related. Examination was repeatedly rejected in the belief that high costs provided an efficient filter of 'frivolous' and poor quality inventions without the need for a new bureaucracy (Dutton 1984: 45). Examination was considered to be not only expensive and impractical (in particular, through a shortage of technically trained personnel) but also potentially unjust (Soul 1869: 6-7). There is evidence, however, that high costs were a very poor substitute: both before and after 1852, they failed as an efficient gatekeeper while continuing to exclude many inventors from access to patent protection.

Under the 1852 act, keeping a UK patent in force for the full fourteen years cost $£ 175$; previously a patent for England and Wales (as the majority had been) cost approximately £110. 'By 1870 , the cost in US dollars of securing patents [in the UK], calculated on the basis of price per annum covered, was considerably higher than elsewhere, by a factor of three compared to Belgium and France, of ten compared to Prussia, and of thirty compared to the United States' (Inkster 2000: 135). The 1883 act lowered the initial fees and extended the first period by a year: $£ 4$ now bought four years of protection, £54 seven years and $£ 154$ fourteen. In 1884, the government bowed to pressure, allowing renewal fees to be paid in instalments: $£ 10$ per annum before the end of years four to 
seven: $£ 15$ per annum at eight and nine; $£ 20$ at ten to thirteen. In 1892, it introduced a sliding scale that started at $£ 5$ after four years and rose, by annual increments of $£ 1$, to $£ 14$ after thirteen - a structure that continued through the twentieth century. This represented a reduction of total renewal fees from $£ 150$ to £95, still higher than campaigners had demanded (and in real terms approximately 12 times more expensive than in 1965), but it was official recognition that the dilemma posed by two large lump-sum payments after four and seven years had been dysfunctional (MacLeod et al. 2003: 538, 547).

A limited examination was introduced by the 1883 act, to check that the specification claimed no more than a single invention and prima facie it was properly described (Hewish 2000: 104-14). However, it was only when the Patents Act of 1902 required an (advisory) examination for prior art (similar inventions described in the previous 50 years' UK patent records) that the UK system ceased to be one of registration: until this came into force in 1905, the burden of scrutiny had lain with the patentee and his or her agent. The Patents and Designs Act of 1907 extended the scope of examination to exclude 'frivolous' patents that were 'contrary to natural laws', and authorised the examiners to refuse a patent for lack of novelty (Van Dulken 2000: 5).

In the absence of examination, many patentees seem to have taken the risk of making no search for prior art. The Fry Committee's scrutiny of 900 specifications in 1901 revealed that 42 per cent had been wholly or partly anticipated (in one case 13 times). Apparently, the situation had deteriorated since 1864, when the Royal Commission found 25 per cent of recent patents in this category (MacLeod et al. 2003: 541-2).

Such patentees were unlikely to be among the 30 per cent of those with a sealed patent who paid the first renewal fee or the 11 per cent who paid the second (MacLeod et al. 2003: 538, n. 8). Their purpose in obtaining a patent may have been primarily defensive: seeking some security against being harassed for royalties by another patentee, or some cheap kudos when advertising their business. It is even harder to explain the enormous increase in provisional (temporary) patents, which from 1852 kept pace with the growth in sealed patents, except by reference to these heterodox reasons. In the UK's system of registration, where very few applications were rejected, the lapsing of a provisional patent normally represented the failure to enter a full specification. Before 1852, 5.4 per cent of patents lapsed because of this (Van Dulken 1999: 31; MacLeod 1988: 48-53). Between 1853 and 1883, 35 per cent of applications obtained no more than provisional protection, rising to 53 percent between 1884 
and 1899 (Boehm and Silberston 1967: 33-4). Again this decision seems to be price sensitive: under the 1852 act, while £5 secured a provisional patent (for six months), another $£ 20$ was needed to seal it; under the 1883 act, the figures fell to $£ 1$ (for ten months) and £3. The fall from $£ 5$ to $£ 1$ seems to have had greater impact on behaviour than that from £20 to £3 (MacLeod et al. 2003: 556-60). Three pounds was still more than a week's wages for most working men.

Contemporary critics of high renewal fees complained that they represented an insuperable barrier to many patentees with technically valuable inventions (MacLeod et al. 2003: 544-6). Yet, as some also suspected, they failed to weed out many valueless inventions such as perpetual motion machines. In 1851, the engineer Richard Roberts criticised the unreformed patent system for harbouring 'a great number of very silly things, which no man who had been long in a workshop would ever think of patenting; and the reason is, that the patentee has money, though deficient in experience and mechanical talent' ([House of Lords] 1851: 422-3). Such patentees might be excused on the grounds that these high fees all had to be paid at the start. It is more surprising that, after 1852, some wasted their money on renewal fees in the light of three or four (or even seven) years' experience. Recent research on steam-engine patents, which employed an engineer to assess the technical viability of abridged specifications, found that in a sample of 56 patents (fully or provisionally specified) obtained in 1855 that he deemed technically unviable, nine were renewed after three years, including two that were also definitely renewed after seven (a third could not be traced). The rate of renewal for these patents, renewed at least once (17 per cent), was not much below that for apparently viable stationary and marine steam engines (25 per cent) (Andrew et al. 2001; MacLeod et al. 2003: 549-54). 


\section{CONCLUDING REMARKS}

Evidently the patent system had close links with industrialisation, but these were not ones of simple cause and effect as implied by North. A patent was an instrument of competition that was growing in value in an increasingly capitalistic, manufacturing economy. We might even reverse the causal arrow: industrialisation promoted the patent system.

The specific characteristics of Britain's patent system were moulded by the circumstances of its development: an oligarchic society produced an oligarchic patent system. Its social bias was sufficiently marked to prompt the head of the judiciary Lord Chancellor Kenyon, while finding in favour of Boulton and Watt in 1799 , to confess to some disquiet: 'it struck him that there was a great deal of oppression of the lower orders of men from patents, by those who were more opulent' (Robinson 1971: 137). ${ }^{15}$ Most eighteenth-century inventors were either ignorant of its existence, or found it too expensive or inconvenient to buy and enforce a patent. In fact, other very effective strategies of appropriation (such as secrecy or a head start in the production or use of the invention) were open to inventors (MacLeod, 1992). Many could see no benefit from patenting their invention in the particular circumstances in which they intended to use it: they proceeded to deploy it unobtrusively in their own business, or they engaged in collective invention. Some retained ethical misgivings about appropriating an invention for personal gain, and others still perceived technical change as a phenomenon subject to divine intervention or 'Providence', for which no individual person merited reward (MacLeod 1988: 202-4, 219-20). Possibly, only a minority calculated that a patent would be a good commercial investment, or that it would be perilous not to obtain one because of the risk of pre-emption.

The conditions for a market in invention were only in their infancy in eighteenthcentury Britain, and the patent system was developed by commercially minded men in order to promote it. This period witnessed market-orientated inventors and investors suffering many frustrations and set-backs as they attempted to educate the government and the judiciary in the role they conceived a patent system should play (Dutton 1984: 37, 42-5; Robinson 1971). With a patent system more in the mould of its more democratic US counterpart, we may speculate that Britain might have enjoyed not only a faster rate of economic growth (through higher rates of invention and its diffusion), but also a greater

${ }^{15}$ Quoted from The Times Law Report, 26 January 1799. 
degree of social mobility, thanks to widened opportunities for the commercialisation of inventions (Khan and Sokoloff 1998: 306). However, it would have required a different type of society to produce such a patent system. On the other hand, those historians such as Khan and Sokoloff who highlight the beneficial role of the more "modern" US patent system on innovative performance throughout the nineteenth century should also recognise in their assessments that Britain, with her very imperfect patent system, was the first industrial nation and at least until the 1850s (if not the 1870s) was the world technological leader (Mokyr, 2002: 295).

With no patent system, investment capital to develop and commercialise the more capital-intensive inventions might have been harder to find. Increasing levels of capital investment in manufacturing industry raised the financial stakes for entrepreneurs (Pollard 1964, Chapman 1970, Feinstein 1978, Cottrell 1980, Crafts 1985: 71-7). Fixed assets in the relatively novel form of buildings and machinery, while opening the way to unprecedented levels of production and profit, also exposed them to new risks: to losses from fire, interruptions of trade or strikes. The insurance industry was developed to offer some security against such risks as fire, and the legislature was mobilised to curtail the power of workers and to deter crimes against property (Supple 1980, Rule 1986, Pearson 2004). Analogously, in the patent system such manufacturers saw an institution that would allow them to manage their investment in new technology - to secure their 'property', and to exclude unauthorised intruders (Greasley and Oxley 2007). 'Few capitalists would invest in invention without the protection of a patent. Inventing was a risky activity and this kind of protection was the only realistic way of appropriating a return sufficient to cover the cost of producing and developing inventive output' (Dutton 1984: 151). It was primarily their interests that shaped the patent system in the two centuries before 1852 and arguably beyond. Yet, beside the incentives to innovate that the patent system may have provided, one should also consider that sometimes patents may have discouraged follow-up innovations. The most poignant case in this respect is that of James Watt's patent for the separate condenser (Torrens, 1982).

Notwithstanding all these considerations, we contend that, given the evidence of widespread inventive activity outside the coverage of patent protection, even with no patent system British inventors would have continued to invent. Perhaps the industrial revolution would not have happened exactly as it did, but the wider and deeper pressures towards industrialisation throughout the western hemisphere at this period imply that it would have occurred in some 
form, more or less at the same time, and most probably first in Britain (Allen 2009).

The implications of our analysis for contemporary debates on patent systems are straightforward. The patent system seems to have had, at best, 'second order' effects on the course of industrial development in Britain. Given the most recent trends towards the extension (e.g., to new life forms, business methods, software programs) and the deepening (measures for ensuring stronger enforcement) of patent systems, which seem to have highly ambiguous effects on both rates of innovation and social welfare at large (Bessen and Maurer 2008, Boldrin and Levine, 2008 ), one cannot avoid the impression that excessive emphasis has been put on the implementation of 'strong' intellectual property rights regimes and that a more sober and pragmatic approach to patent reform is in order. 


\section{REFERENCES}

Adams, John N., and Averley, Gwen (1986), 'The patent specification, the role of Liardet $v$ Johnson', Journal of Legal History, 7, 156-79

Allen, R. C. (1983), 'Collective invention', Journal of Economic Behavior and Organization, 4, 1-24

Allen, R. C. (2008), 'The nitrogen hypothesis and the English agricultural revolution: a biological analysis', Journal of Economic History, 68, 182-210

Allen, R. C. (2009), The British Industrial Revolution in Global Perspective, Cambridge: Cambridge University Press

Andrew, James, Tann, Jennifer, MacLeod, Christine, and Stein, Jeremy (2001), 'Steam power patents in the nineteenth century: innovations and ineptitudes', Transactions of the Newcomen Society, 72, 17-38

Ashton, T. S. (1948), The Industrial Revolution, 1760-1830, Oxford and New York: Oxford University Press

Bairoch, Paul (1973), 'Agriculture and the industrial revolution, 1700-1914', in Carlo Cipolla (ed.), The Fontana Economic History of Europe, vol. 3, London: Collins/Fontana

Belfanti, Carlo M. (2004), 'Guilds, patents and the circulation of technical knowledge: Northern Italy during the early modern age', Technology and Culture, 45, 569-89

Berg, Maxine (1991) 'Commerce and creativity in eighteenth-century Birmingham', in Maxine Berg (ed.), Markets and Manufacture in Early Industrial Europe, London: Routledge

Berg, Maxine (1998), 'Product innovation in core consumer industries in eighteenth-century Britain', in Maxine Berg and Kristine Bruland (eds.), Technological Revolutions in Europe, Historical Perspectives, Cheltenham and Northampton, MA.: Edward Elgar, 138-60

Berg, Maxine (1994), The Age of Manufactures, 1780-1820: Industry, Innovation and Work in Britain, 2nd edn, London and New York: Routledge 
Berg, Maxine, and Hudson, Patricia (1992), 'Rehabilitating the industrial revolution', Economic History Review, 45, 24-50

Bessen, J. and Meurer, M. J. (2008), Patent Failure, Princeton: Princeton University Press

Biagioli, Mario (2006), 'From print to patents: living on instruments in early modern Europe', History of Science, 44, 139-86

Boehm, K. and Silberston, A. (1967), The British Patent System: Administration, Cambridge: Cambridge University Press.

Boldrin, Michele and Levine, D. (2008), Against Intellectual Monopoly, Cambridge: Cambridge University Press.

Brunt, L., Lerner, J. and Nicholas, T. (2008), 'Inducement prizes and innovation', CEPR Working Paper, n. 6917.

Cannadine, David (1984), 'The present and the past in the English industrial revolution', Past \& Present, 103, 131-72

Carreras, Albert and Josephson, Camilla (2010), 'Growing at the production frontier: European aggregate growth, 1870-1914', in S. Broadberry and K. O'Rourke (eds.), The Cambridge Economic History of Modern Europe, vol. 2, Cambridge: Cambridge University Press

Chang, H-J. (2001), 'Intellectual property rights and economic development: historical lessons and emerging issues', Journal of Human Development, 2, 287-309

Chapman, S. D. (1970), 'Fixed capital formation in the British cotton industry, 1770-1815', Economic History Review, 23, 235-66

Cipolla, Carlo M. (1962), The Economic History of World Population, Harmondsworth: Penguin Books

Cohen, Wesley, Nelson, Richard R., and Walsh, John P. (2000), 'Protecting their intellectual assets: appropriability conditions and why U.S. manufacturing firms patent (or not).', NBER Working Paper n. 7552

Coleman, D. C. (1992), Myth, History and the Industrial Revolution, London and Rio Grande: The Hambledon Press 
Cookson, Gillian (1997), 'Family firms and business networks: textile engineering in Yorkshire, 1780-1830', Business History, 39, 1-20

Cottereau, Alain (1997), 'The fate of collective manufactures in the industrial world: the silk industries of Lyons and London, 1800-1850', in C. Sabel and J. Zeitlin (eds.), Worlds of Possibilities, Cambridge: Cambridge University Press, $75-152$

Cottrell, Philip L. (1980), Industrial Finance, 1830-1914: the Finance and Organization of English Manufacturing Industry, London: Methuen

Coulter, Moureen (1992), Property in Ideas: the Patent Question in midVictorian Britain, Kirksville, MO: Thomas Jefferson Press

Crafts, N. F. R. (1985), British Economic Growth during the Industrial Revolution, Oxford: Clarendon Press

Crafts, N. F. R. (2004), 'Steam as a general technology: a growth accounting perspective', Economic Journal, 114, 338-51

Crafts, N. F. R. and Harley, C. K. (1992), 'Output growth and the British industrial revolution: a restatement of the Crafts-Harley view', Economic History Review, 45, 703-30

Davids, Karel (1995), 'Shifts of technological leadership in early modern Europe', in Karel Davids and Jan Lucassen (eds.), A Miracle Mirrored: the Dutch Republic in European Perspective, Cambridge: Cambridge University Press, 338-67

Davids, Karel (2008), The Rise and Decline of Dutch Technological Leadership: Technology, Economy and Culture in the Netherlands, 1350-1800, 2 vols., Leiden: Brill

[Dickens, Charles] (1850), 'A poor man's tale of a patent', Household Words, 19 October 1850, 73-5

Dickens, Charles (1967), Little Dorrit, Harmondsworth: Penguin Books

Dickinson, H. W. and Jenkins, Rhys (1981), James Watt and the Steam Engine, with introduction by Jennifer Tann, 2nd edn, Ashbourne: Moorland 
Duncan, G. D. (1976), 'Monopolies under Elizabeth I', unpubl. PhD thesis, University of Cambridge

Dutton, H. I. (1984), The Patent System and Inventive Activity during the Industrial Revolution, Manchester: Manchester University Press

Epstein, S. R. (1998), 'Craft guilds, apprenticeship, and technological change in preindustrial Europe', Journal of Economic History, 58, 684-713

Feinstein, Charles H. (1978), 'Capital formation in Great Britain', in Peter Mathias and M. M. Postan (eds.), Cambridge Economic History of Europe, vol. 7, pt 1, Cambridge: Cambridge University Press, 28-96

Feinstein, C. H. (1998), 'Pessimism perpetuated: real wages and the standard of living in Britain during and after the industrial revolution', Journal of Economic History, 58, 625-58

Flinn, Michael (1984), The History of the British Coal Industry, 1700-1830, Oxford: Clarendon Press

Foray, Dominique, and Hilaire-Pérez, Liliane (2006), 'The economics of open technology: collective organisation and individual claims in the "fabrique lyonnaise" during the Old Regime', in Cristiano Antonelli et al (eds.), New Frontiers in the Economics of Innovation and New Technology: Essays in Honor of Paul A. David, Cheltenham and Northampton, MA: Edward Elgar

Freeman, Christopher (1994), 'The economics of technical change', Cambridge Journal of Economics, 18, 463-514

Frumkin, Maximilian (1947), 'Early history of patents for invention', Transactions of the Newcomen Society, 26, 47-55

Galvez-Behar, Gabriel (2008), La République des inventeurs: Propriété et organisation de l'innovation en France (1791-1922), Rennes: Presses Universitaires de Rennes

Gomme, A. A. (1934-5), 'Patent practice in the eighteenth century: the diary of Samuel Taylor, threadmaker and inventor, 1722-3', Transactions of the Newcomen Society, 15, 210-16

Gomme, Allan A. (1946) Patents of Invention: Origin and Growth of the Patent System in Britain, London: Longmans Green for the British Council 
Greasley, David, and Oxley, Les (2007), 'Patenting, intellectual property rights and sectoral outputs in industrial revolution Britain, 1780-1851', Journal of Econometrics, 139, 340-54

Harris, J. R. (1976), 'Skills, coal, and British industry in the eighteenth century', History, 61, 167-82

Heerding, A. (1985), The History of N.V. Philips' Gloeilampenfabriken. Vol I. The Origin of the Dutch Incandescent Lamp Industry, Cambridge: Cambridge University Press.

Hewish, John (2000), Rooms near Chancery Lane: the Patent Office under the Commissioners, 1852-1883, London, British Library Board

Hilaire-Pérez, Liliane (2000), L'Invention technique au siècle des Lumières, Paris: Albin Michel

Hobsbawm, Eric J. (1962), The Age of Revolution, 1789-1848, London: Weidenfeld and Nicolson

Holdsworth, W. (1922-72), A History of English Law, 17 vols., London: Methuen

[House of Lords] (1851), Select Committee of the House of Lords appointed to consider the Bills for the amendment of the Law touching Letters Patent for Invention, Reports and Minutes of the Evidence, British Parliamentary Papers 1851, XVIII

Hulme, E. W. (1917), 'Privy Council law and practice of letters patent for invention from the Restoration to 1794', Law Quarterly Review, 33, 63-75, 18195

Hunter, L. C. (1949), Steamboats on the Western Rivers: An Economic and Technological History, Cambridge MA: Harvard University Press

Inikori, Joseph E. (2002), Africans and the Industrial Revolution in England, Cambridge: Cambridge University Press

Inkster, Ian (2000), 'Machinofacture and technical change: the patent evidence', in Ian Inkster, Colin Griffin, Jeff Hill and Judith Rowbotham (eds.), The Golden Age: Essays in British Social and Economic History, 1850-1870, Aldershot: Ashgate 
Jeremy, David J. (1973), 'British textile technology transmission to the United States: the Philadelphia region experience', Business History, 47, 24-52.

Kanefsky, J. W. (1979), 'The diffusion of power technology in British industry, 1760-1870', unpubl. PhD thesis, University of Exeter

Khan, B. Zorina (2005), The Democratization of Invention: Patents and Copyrights in American Economic Development, 1790-1920, Cambridge: Cambridge University Press.

Khan, B. Zorina (2010), 'Looking backward: founding choices in innovation an intellectual property protection', mimeo.

Khan, B. Zorina, and Sokoloff, Kenneth L. (1998), 'Patent institutions, industrial organization and early technological change: Britain and the United States, 1790-1850', in Maxine Berg and Kristine Bruland (eds.), Technological Revolutions in Europe, Historical Perspectives, Cheltenham and Northampton, MA.: Edward Elgar, 292-313

Khan, B. Zorina, and Sokoloff, Kenneth L. (2001), 'The early development of intellectual property institutions in the United States', Journal of Economic Perspectives, 15, pp. 233- 46

Kyriazidou, E. and Pesendorfer, M. (1999), 'Viennese chairs: a case study for modern industrialisation', Journal of Economic History, 59, 143-66

Landes, David S. (1969), The Unbound Prometheus: Technological Change and Industrial Developments in Western Europe, from 1760 to the Present, Cambridge: Cambridge University Press

Levin, Richard C., Klevorick, Alvin K., Nelson, Richard R., Winter, Sidney G., Gilbert, Richard, and Griliches, Zvi (1987), 'Appropriating the returns from industrial R\&D.' Brookings Papers on Economic Activity, 3, 783-831.

Long, Pamela O. (1991), 'Invention, authorship, "intellectual property" and the origins of patents: notes towards a conceptual history', Technology and Culture, $32,846-84$

McCloskey, D. N. (1981), 'The industrial revolution, 1780-1860: a survey', in Roderick Floud and D. N. McCloskey (eds.), The Economic History of Britain since 1700, vol. I, Cambridge: Cambridge University Press, 103-27 
McConnell, Anita (2007), Jesse Ramsden (1735-1800) London's Leading Scientific Instrument Maker, Aldershot and Burlington, VT: Ashgate

McGaw, Judith A. (1987), Most Wonderful Machine: Mechanization and Social Change in Berkshire Paper Making, 1801-1885, Princeton: Princeton University Press

McGee, David (1995), 'Making up mind: the early sociology of invention', Technology and Culture, 36, 773-801

Machlup, F. (1958), An Economic Review of the Patent System, Washington: Government Printing Office.

Machlup, F. and Penrose, E. (1950), 'The patent controversy in the nineteenth century', Journal of Economic History, 10, 1-29

MacLeod, Christine (1986), 'The 1690s patents boom: invention or stockjobbing?', Economic History Review, 39, 549-71

MacLeod, Christine (1988) Inventing the Industrial Revolution: the English Patent System, 1660-1800, Cambridge: Cambridge University Press

MacLeod, Christine (1991), 'The paradoxes of patenting: invention and its diffusion in 18th- and 19th-century Britain, France, and North America', Technology and Culture, 32, 885-910

MacLeod, Christine (1996), 'Concepts of invention and the patent controversy in Victorian Britain', in Robert Fox (ed.), Technological Change: Methods and Themes in the History of Technology, Amsterdam: Harwood Academic Publishers, 137-54

MacLeod, Christine (2004), 'The European origins of British technological predominance', in L. Prados de la Escosura (ed.), Exceptionalism and Industrialisation: Britain and its European Rivals, 1688-1815, Cambridge: Cambridge University Press, 111-26

MacLeod, Christine (2007), Heroes of Invention: Technology, Liberalism and British Identity, 1750-1914, Cambridge: Cambridge University Press

MacLeod, Christine, Tann, Jennifer, Andrew, James, and Stein, Jeremy (2003), 'Evaluating inventive activity: the cost of nineteenth-century UK patents and the fallibility of renewal data', Economic History Review, 56, 537-62 
Mak, J. and Walton, G. M. (1972), 'Steamboats and the great productivity surge in river transportation', Journal of Economic History, 32, 619-40

Mantoux, Paul (1928), The Industrial Revolution in the Eighteenth Century: An Outline of the Beginnings of the Modern Factory System in England, trans, Marjorie Vernon, London: Jonathan Cape

Mathias, Peter (1969), The First Industrial Nation: An Economic History of Britain, 1700-1914, London: Methuen

May, Christopher (2002), 'Antecedents to intellectual property: the European pre-history of the "ownership" of knowledge', History of Technology, 24, 1-20

Miller, David P. (2006), 'Watt in court: specifying steam engines and classifying engineers in the patent trials of the 1790s', History of Technology, 27, 43-76

Mitchell, B. R., and Deane, Phyllis (1962), Abstract of British Historical Statistics, Cambridge: Cambridge University Press

Mokyr, Joel (1990), The Lever of Riches: Technological Creativity and Economic Progress, Oxford and New York: Oxford University Press

Mokyr, Joel (2002), The Gifts of Athena: Historical Origins of the Knowledge Economy, Princeton and Oxford: Princeton University Press

Mokyr, Joel (2008), 'The institutional origins of the Industrial Revolution' in E. Helpman (ed.), Institutions and Economic Performance, Cambridge, MA: Harvard University Press

Moser, Petra (2005), 'How do patent laws influence innovation? Evidence from nineteenth-century world fairs', American Economic Review, 95, 1213-36

Moser, Petra (2010), 'Innovation without patents. Evidence from world fairs', mimeo.

Murmann, J. P. (2003), Knowledge and Competitive Advantage: The Coevolution of Firms, Technology and National Institutions, Cambridge: Cambridge University Press

Musson, A. E. (1976), 'Industrial motive power in the United Kingdom, 18001870', Economic History Review, 29, 415-39 
Nef, J. U. (1932), The Rise of the British Coal Industry, London: G. Routledge \& Sons

North, Douglass C. (1981), Structure and Change in Economic History, New York and London: W. W. Norton

North, Douglass C. and Thomas, Robert P. (1973), The Rise of the Western World: A New Economic History, Cambridge: Cambridge University Press

Nuvolari, Alessandro (2004), 'Collective invention during the British industrial revolution: the case of the Cornish pumping engine', Cambridge Journal of Economics, 28, 347-63

Nuvolari, Alessandro (2005), 'Open source software development: some historical perspectives', First Monday, Vol 10 (10), available at http://www.firstmonday.org/issues/issue10 10/nuvolari/index.html

Nuvolari, Alessandro and Tartari, Valentina (2010), 'Bennet Woodcroft and the value of English patents, 1617-1841', mimeo.

O’Brien, Patrick, Griffiths, Trevor, and Hunt, Philip (1996), 'Technological change during the first industrial revolution: the paradigm case of textiles, 16881851', in Robert Fox (ed.), Technological Change: Methods and Themes in the History of Technology, Amsterdam: Harwood Academic Publishers, 155-76

Olmstead, Alan L., and Rhode, Paul W. (2008), Creating Abundance. Biological Innovation and American Agricultural Development, Cambridge: Cambridge University Press.

Paulinyi, A. (1986), 'Revolution and technology', in Roy Porter and Mikulas Teich (eds.), Revolution in History, Cambridge: Cambridge University Press

Pearson, Robin (2004), Insuring the Industrial Revolution: Fire Insurance in Great Britain, 1700-1850, Aldershot: Ashgate

Penrose, Edith Tilton (1951), The Economics of the International Patent System, Baltimore, Johns Hopkins University Press

Plant, Arnold (1934), 'The economic theory concerning patents for inventions', Economica, n.s. 1, 30-51 
Pollard, Sydney (1964), 'Fixed capital in the industrial revolution in Britain', Journal of Economic History, 24, 299-314

Pollard, Sydney (1981), Peaceful Conquest: The Industrialization of Europe, 1760-1970, Oxford: Oxford University Press

Pomeranz, Kenneth (2000), The Great Divergence: Europe, China and the Making of the Modern World Economy, Princeton, NJ: Princeton University Press

Richter, R. and Streb, J. (2009), 'Catching up and falling behind: knowledge spillovers from American to German machine tool makers', FZID Discussion Papers, University of Hohenheim.

Robinson, Eric (1971), 'James Watt and the law of patents', Technology and Culture, 12, 115-39

Rosenberg, Nathan (1976), Perspectives on Technology, Cambridge: Cambridge University Press

Rule, John (1986), The Labouring Classes in Early Industrial England, 17501850, London: Longman

Samuel, Raphael (1977), 'Workshop of the world: steam power and hand technology in mid Victorian Britain', History Workshop Journal, 3, 6-72

Saxonhouse, G. (1974), 'A tale of Japanese technological diffusion in the Meiji period', Journal of Economic History, 34, 149-65

Schiff, Eric (1971), Industrialisation without National Patents: the Netherlands 1869-1912; Switzerland, 1850-1907, Princeton: Princeton University Press

[Select Committee on Patents] (1829), Report from the Select Committee Appointed to Inquire into the Present State of the Law and Practice Relative to the Granting of Patents for Inventions, British Parliamentary Papers, 1829, III

Shah, S. K. (2005), 'Open beyond software', in C. Di Bona, D. Cooper, and M. Stone (eds), Open Sources 2, Sebastopol: O' Reilly

Sokoloff, Kenneth L. (1988), 'Inventive activity in early industrial America: evidence from patent records, 1790-1846', Journal of Economic History, 48, 813-50 
Sokoloff, Kenneth L., and Khan, B. Zorina (1990), 'The democratization of invention during early industrialisation: evidence from the United States, 17901846', Journal of Economic History, 50, 363-78

Soul, Matthew A. (1869), Reform of the Patent Laws: A Working Men's Question, London

Sullivan, Richard J. (1989), 'England's "Age of Invention”: the acceleration of patents and of patentable invention during the industrial revolution', Explorations in Economic History, 26, 424-52

Supple, Barry E. (1970), The Royal Exchange Assurance: A History of British Insurance, 1720-1970, Cambridge: Cambridge University Press

Tann, Jennifer (1988), 'Fixed capital formation in steam power', in Charles $\mathrm{H}$. Feinstein and Sidney Pollard (eds.), Studies in Capital Formation, 1750-1920, Oxford: Clarendon Press, 164-81

Thirsk, Joan (1978), Economic Policy and Projects: The Development of a Consumer Society in Early Modern England, Oxford: Oxford University Press

Thomas, Brinley (1985), 'Escaping from constraints: the industrial revolution in a Malthusian context', Journal of Interdisciplinary History, 15, 729-53

Torrens, H. S. (1982), 'New light on the Hornblower and Winwood compound steam engine', Journal of the Trevithick Society, 3, 21-41

Van Dulken, Stephen (1999), British Patents for Invention, 1617-1977: A Guide for Researchers, London: British Library Board

Van Zanden, J. L. and Van Riel, A. (2004), The Strictures of Inheritance: The Dutch Economy in the Nineteenth Century, Princeton: Princeton University Press

Von Hippel, E. (2005), Democratizing Innovation, Cambridge, MA: MIT Press

Von Tunzelmann, G. N. (1978), Steam Power and British Industrialization to 1860, Oxford: Clarendon Press

Von Tunzelmann, G. N. (1981), 'Technical progress during the industrial revolution', in Roderick Floud and D. N. McCloskey (eds.), The Economic 
History of Britain since 1700, vol. I, Cambridge: Cambridge University Press, 143-63

Wallace, A. F. and Jeremy, D, J. (1977), 'William Pollard and the Arkwright patents', William and Mary Quarterly, 34, 404-425.

Wrigley, E. A. (1985), 'Urban growth and agricultural change: England and the Continent in the early modern period', Journal of Interdisciplinary History, 15, 683-728.

Wrigley, E. A. (1988), Continuity, Chance and Change: The Character of the Industrial Revolution in Britain, Cambridge: Cambridge University Press

Yamomoto, Koji (2010), 'Distrust, innovation and public service: projecting in seventeenth- and early eighteenth-century England', unpubl. PhD, University of York 